\title{
Battle of Sexes in the Workplace
}

\section{Prof. Suzette DC. Domingo and Dr. Walter P. Salva}

College of Management and Business Technology, Nueva Ecija University of Science and Technology, Nueva Ecija, Philippines

\begin{abstract}
This study was undertaken to present the functions of gender for promotion and describe the forms of gender discrimination in the workplace.

The researchers present knowledge about the Gender discrimination in the workplace and the study is deemed significant for it benefit the following sectors and groups of person;

This study is therefore useful socially, economically and academically. Socially it enables employees to co -exist peacefully without discriminating against others due to their ethnic background, gender or race.

The researchers used descriptive method, method of research which is a fact-finding study with adequate and accurate interpretation of data. It describes with emphasis what actually exist such as the current condition of the phenomenon.
\end{abstract}

The respondents of the study were the employees and employers of selected business establishments in Cabanatuan city.

First, the researchers presented the profile of the respondents as to age; sex; highest educational attainment; length of service and period of promotion granted. Next is the functions of sex in promotion and the forms of discrimination in the workplace.

For the summary of findings and conclusions, majority of the respondents are not new in their work, female dominated the study, respondents were promoted after their provisionary period. Female are more supportive and approachable while male are more cooperative in the study. The respondents are continue seeking knowledge to be promoted or to have a higher position. Respondents are not new in service or in their job. Respondents are promoted after their provisionary period. Male easy recognize the scenario and straight forward in decision making. Men prefer a hierarchical leadership structure because it allows for easier role clarity and delegation of authority. Employers and employees are both believe in the patriarchal leadership that male are superior but women communicate properly in the workplace because they are more perfectionist and meticulous. Male are direct to the point in controlling the organization, they do not use any further words to give their thought unlike women. And it is not usual for male to have corrective actions in every undertakings. Women are more efficient and almost perfectionist in all actions to be done. Women are less competent than men and lacking in leadership potential, because of these perceptions, women encounter greater challenges to or skepticism of their ideas and abilities at work. Men and women are correctly predicting the differential experiences that they would encounter with professional advancement and are making sound decisions. It is also possible that women are overestimating the negative consequences associated with power, that men are underestimating them, or both.

Keywords-Gender Descrimination, workplace, planning.

\section{INTRODUCTION}

Gender Discrimination is not an issue, which one can ignore or tolerate silently. People should realize that gender discrimination at workplace is a serious form of employment discrimination, which should not be discharged. Gender based discrimination is defined as undesirable action or differential treatment against a person that would not have occurred if the person had been of another sex. Gender Discrimination is considered as a serious form of injustice and it is illegal in certain circumstances in most of the countries around the world.

Women still face a gender bias - especially in the workforce. Despite the best efforts of companies to promote diversity and equality, women still dominate the lower paying administrative ranks while men continue to dominate at the executive level. This inequality is hurting corporate performance. Today's women want it all - like 
their male counterparts. And a few are succeeding - but only a few.

\section{Conceptual Framework}

Peters on and Thea (2006) describe that there are so many ways of the gender biasness and discrimination in organizations due to the unfair actions of the employer; discrimination in job compensation package, hiring discrimination, favoritism related to job promotion, and biasness in wage setting for different type of job work. Many analysts agree on this "hiring is most important; promotion is second; and wages are third."

Elisabeth K. Kelan (2009) claimed that genderquake is disturbing gender terms and relations dramatically. It looks like that western well developed countries are well aware this issue but don ${ }^{e t}$ like to address gender biasness and inequality among male and female employee.

\section{Objectives}

1.To present the profile of the respondents.

2.To describe the functions of sex in promotion in the workplace.

3. To identify the forms of Descrimination in the work place.

\section{METHODOLOGY}

In this study, the researchers used of the descriptive method of research. According to (Calderon, 2007) descriptive method of research is a fact-finding study with adequate and accurate interpretation of data. It describes with emphas is what actually exist such as the current condition of the phenomenon.

Descriptive research describe what is and is concerned with the condition or relationships that exist, practices that prevail, processes that are ongoing or trends that developing (Manuel and Mendel, 1990).

The researchers used the descriptive survey type of descriptive research, because the researcher intended to gather relatively limited data from a relatively large number of cases. Another reason is that a survey is useful in improving the value of fact and focusing attention on the most important things to be reported.

\section{The Research Locale}

The data gathering conducted in Cabanatuan City. The researchers chose the local base on their own interest and also the prevalence of issues that concerns the research paper.
Table 1

Classification of respondents

$\begin{array}{cll} & \mathrm{N} & \mathrm{n} \\ \text { Employers } & 9 & 8 \\ \text { Employees } & 91 & 67 \\ \quad \text { Total } & 100 & 75\end{array}$

Table 1 shows the classification of respondents, it is clearly presented that the expected respondents for this study were 9 employers and 91 employees 100, however during the retrieval of the questionnaire checklist some of them were absent, thus, the total respondents are 75 based from the retrieved copies of questionnaire.

\section{Sampling Design}

The researchers employed purposive random sampling. Purposive Sampling technique means choosing the sample with an underlying purpose. The researchers may wish to make particular point and chose sample with their purpose in mind.

\section{Data Gathering Technique}

The researchers sought the assistance of respondents to come up with analysis interpretation and conclusions of the study entitled "Battle of Sexes in the Workplace: An Assessment"

The researchers administered questionnaires to the respondents employed in Cabanatuan City and as a result, it helps in bringing ideas on the subject studied.

Also, the researchers employed personal interviews and observation in some instances, such as when certain information seems not accurate.

\section{Research Instrumentation}

The research instrument used in data gathering is questionnaire checklist. It is the most appropriate tool in collecting data, all information the researchers want to know are already there and the respondents answered based on the options given.

The questionnaire checklist was modified from "Adhikari, S. (2014). Impact of Gender Discrimination at Workplace. "

\section{Statistical Treatment of Data}

The researcher used the following statistical tools. Frequency Distribution

It is tabular arrangement of data by classes or categories together with their corresponding class frequencies. Class frequency refers to the number of the observations belonging to a class interval, or the number of the items within the categories a class interval is a grouping 
or category defined by a lower limit band upper limit (Tan, 2006).

$\mathrm{P} \%=\mathrm{F} / \mathrm{N} X 10 \mathrm{O}$

\section{Summary of findings}

The researchers used Descriptive method ,because it describe what is and is concerned with the condition or relationships that exist, practices that prevail, processes that are ongoing or trends that developing. The respondents were the employers and employees of the selected business establishment in Cabanatuan City.

\section{Profile of the Respondents}

Age majority of the respondents belong to 31-35 years old with 30 or $40 \%$,followed by 15 or $20.00 \%$ belong to $26-30$ years old ,there are 14 or $18.67 \%$ belong to 36040 years old,10 or $13.33 \%$ belong to $20-25$ years old, while the least number of respondents belong to 41 years old and above with 6 or $8.00 \%$.

Sex, in majority of the respondents are female with 47 or $62.67 \%$ and 28 or $37.33 \%$ male.

Highest educational attainment majority of them earned Bachelor's degree with 29 or $38.67 \%$,followed by 21 or $28.00 \%$ earned MA units,while 18 or $24.00 \%$ of them finished MA and only 7 or $9.33 \%$ has Ph.D. units.

Length of service majority of them with 29 or $38.67 \%$ belong to 8 to 10 years and above, followed by 17 or $22.67 \%$ belong to $3-5$ years, while 10 or $13.33 \%$ belong to $1-3$ years in service ,9 or $12.00 \%$ belong to 5 to 8 years.

Period of Promotion Granted majority of them with 39 or $52.00 \%$ belong to 3 years followed by 15 or $20.00 \%$, 10 or $13.33 \%$ belong to five years and the least period of promotion with 7 or $9.33 \%$ belong to 8 years.

\section{Function of sex for promotion}

Planning the perception of employers it has a total weighted mean of 4.06 and verbal interpretation of Agree, the highest mean from the statement according to the perception of employers is the statement number 3 " 1 .

Male are good in visualization and formation of proposed activities" followed by "Male are future-oriented" with a mean of 3.87 and verbal interpretation of Agree,and statement number 2" Male are good programmers" with a mean of 3.80. It implies that male easy recognize the scenario and straight forward in decision making while in the perception of the employees, it has a total weighted mean of 4.30 and verbal interpretation of agree, from the table of employees the statement with the highest mean is the statement number 2 "Male are good programmers" with a mean of 4.54 and verbal interpretation of Strongly agree,followed by statement number 1 " 1 .

Organizing perception of the employers has a total weighted mean of 3.76 and verbal interpretation of Agree, from the table of employers statement number 3 "Male are well delegated their employers /employees to the assign task" got the highest mean 3.90 and verbal interpretation of agree,followed by statement number 1 "Male are more systematic in handling employees" with a mean of 3.70 then statement number 2 "Male are good in establishing relationship with their employers/employees" has a mean of 3.67 and verbal interpretation of Agree.

Leading from the employers perception has a total weighted mean of 3.82 and verbal interpretation of agree, from the employers' table,statement number 2 "Male are best in motivating and inspiring their employees" got the highest mean of 3.90 ,followed by statement number 1 " Male possess good leadership skills" with a mean of 3.87 and statement number 3" Male communicate effectively" with a mean of 3.70 and all are verbally interpreted Agree. Controlling, it has total weighted mean in the employers' perception is 3.56 and verbal interpretation of Agree ,among the statement, statement number 2 "Male are good instructors" got the highest mean and statement 3" Male are very effective in taking corrective actions in every undertaking" got the lowest mean.

Forms of Discrimination in the workplace from the perception of employers has a total weighted mean of 2.88 and verbal interpretation of Undecided, and the highest weighted mean is the statement number 2 "Gender Entry Gap: Discrimination is there at the time of recruitment on the basis of gender. Males are given preference over female for higher or top level position in the organization" with a mean of 4.02 and verbal interpretation of agree and the lowest is the statement number 4" Sexual Harassment: Demand is made of sexual activities and favors in tern of giving promotion or employment" with a mean of 1.86 and verbal interpretation of disagree..

\section{CONCLUSIONS}

Based from the summary of findings the following conclusions were drawn;

1. Female are more supportive and approachable while male are more cooperative in the study.

2. The respondents are continue seeking knowledge to be promoted or to have a higher position.

3. Respondents are not new in service or in their job. 
4. Respondents are promoted after their provisionary period.

5. Male easy recognize the scenario and straight forward in decision making.

6. Men prefer a hierarchical leadership structure because it allows for easier role clarity and delegation of authority.

7. Employers and employees are both believe in the patriarchal leadership that male are superior but women communicate properly in the workplace because they are more perfectionist and meticulous .

8. Male are direct to the point in controlling the organization ,they do not use any further words to give their thought unlike women. And it is not usual for male to have corrective actions in every undertakings . Women are more efficient and almost perfectionist in all actions to be done.

9. Women are less competent than men and lacking in leadership potential, because of these perceptions, women encounter greater challenges to or skepticism of their ideas and abilities at work.

10. Men and women are correctly predicting the differential experiences that they would encounter with professional advancement and are making sound decisions. It is also possible that women are overestimating the negative consequences associated with power, that men are underestimating them, or both.

\section{RECOMMENDATION}

Based from the summary of findings and conclusions, the following recommendations are offered;

1. Men should know how to deal with other people and not sorting the age, civil status specially the sex of a pers on

2.Some of the respondents should continue their studies.

3.Respondents should aim for a higher position

4.Women should learn to stick in their decision.

5.Women should not be emotional in their workplace to avoid flat organizational structure .

6.Employers should pay attention to the capability of women to lead ,they should have gender sensitivity in their workplace.

7.Men should learn to accept mistakes in a nice way in order for them to learn from it.

8. Women should know how to address adversity in order to show their potential to lead.
9. Everyone should accept the fact that empowering women is one of the issues of globalization in the workplace for production, development and competence.

\section{REFERENCES}

[1] Babcock, L., \& Laschever, S. (2003). Women don't ask Negotiation and the gender divide.Princeton: Princeton University.

[2] Babcock, L. (2008). What happens when women don't ask? Negotiation, 11(96), 1- 4.

[3] Beckman, D. \&Menkhoff, L. (2008). Will women be women? Analyzing the gender difference among financial experts. Kyklos, 61(3), 364-384.

[4] Blau, F., \& Kahn, L. (2004, July 16). Rising Wage Inequality and the U.S. Gender Gap. American Economic Review.Retrieved December 4, 2013, from www.ilr.cornell.edu/extension/files/20010919034043pub226.pdf

[5] Brown, D., Brown, D., \&Anastasopoulos, V. (2002, March 4). Women on Boards: Not Just the Right Thing But the Bright Thing. Conference Board of Canada. Retrieved December 2, 2013, from www.europeanpwn.net/files/women on boards canada.pdf

[6] Burnette, J. (2009, March 3). H-Net Reviews. H-Net: Humanities and Social Sciences Online. Retrieved March 12, 2013, from http://www.hnet.org/reviews/showrev.php?id=23001

[7] Compton, M. (2007). The Gender Pay Gap. Women In Business, 59(6), 32-34.

[8] Correll, S., \& Ridgeway, C. (n.d.). Expectation States Theory. Springer - International Publisher Science, Technology, Medicine. Retrieved April 10, 2013, from http://www.springer.com/cda/content/.../cda.../97803873251 56- c2.pdf?

[9] Eagly, Alice $\mathrm{H}$ and Carli, Linda A. 2007. Women and the Labyrinth of Leadership.

[10] Erik, Bihagen., Marita Ohls. (2006). The glass ceiling-where is it? Women's and men's career prospects in the private vs. the public sector in Sweden 1979-2000. The Sociological Review, 54(1), 20-47.

[11] Farrell, W. (2005). Why men earn more. New York: Amacon. Federal Glass Ceiling Commission. (1995, March). Good for business: Making full use of the nations human capital (1-257). Washington D.C. Retrieved March 1, 2009, from

http://www.dol.gov/oasam/programs/history/reich/reports/ce iling.pdf

[12] Gayle, G. L., Golan, L., \& Miller, R. A. (2008, November). Are there glass ceilings for female executives? Pittsburgh: Carnegie Mellon University, Tepper School of Business. Retrieved March 1, 2009, from 
http://comlabgames.com/ramiller/working_papers/GC10070 8.pdf

[13] Habib, Zafarullah. (2000).Through the brick wall and the glass ceiling: women in the civil services in Bangladesh. Gender, Work and Organization, 7(3), 197-209.

[14] Hiau, Joo. Kee. (2008). Glass ceiling or sticky floor exploring the Australian gender pay gap. The Economic Record, 82(59), 408-427.

[15] John, M. Ivancevich. (2004). Human Resource Management ( 9 th edition). McGraw Hill, USA

[16] Kaifi, B.A. (2013). Organizational Behavior: Managing and Leading Organizations.

[17] Kalnická,V., Men and women in managerial positions. Survey information, IVVM 00-07, 2000.

[18] Katty Kay and Claire Shipman (2014) T confidence Gap https://www.theatlantic.com/magazine/archive/2014/05/theconfidence-gap/359815/

[19] LiorShub(2017) THE BLOG 08/10/2016 05:33 pm ET Updated Aug 11, 20175 Reasons Why It's Lonely Being A Female Programmer

[20] Northouse, P. G. (2004). Leadership: Theory and Practice (5th edition). Los Angeles: Sage Publications.

[21] Lockhart, N., \& Pergande, J. (2001). WOMEN WHO ANSWERED THE CALL: World War II as a Turning Point for Women in the Workforce. Journal Of Women's History, 13(2), 154.

[22] Maru, J. (2012, February 3). The Prevalence of Gender Discrimination in the Workforce. GoArticles.com. Retrieved April 16, 2013, from goarticles.com/article/The-Prevalenceof-Gender-Discrimination-in-theWorkplace/6043364/

[23] McLaughlin, H., Uggen, C., \& Blackstone, A. (2012). Sexual Harassment, Workplace Authority, and the Paradox of Power. American Sociological Review, 77(4), 625-647. doi: $10.1177 / 0003122412451728$

[24] Melymuka, K. (2000). Wanted: A workplace without a 'ceiling'.Computerworld, 34(4), 50.

[25] Nelson, Colleen McCain. "Poll: Most Women See Bias in the Workplace - WSJ.com." The Wall Street Journal. N.p., 12 Apr. 2013. Web. 12 June 2013. This article helped us to solidify the argument that discrimination against women in the workforce is a prevalent issue faced by millions of women. The article supported our hypothesis with quantitative data from national surveys.

[26] Rosefed, R. A., Kallerberg, A.L. (1990). A cross national comparison of the gender gap in the income. American Journal of Sociology, 96(1), 69-106.

[27] Smith, Jester, JD. "The Prevalence of Gender Discrimination in the Workplace." Goarticles.com. N.p., 03 Feb. 2011. Web.

[28] Stockdale, M., \& Nadler, J. (n.d.). Paradigmatic Assumptions of Disciplinary Research on Gender Disparities: The Case of Occupational Sex Segregation Springer. Springer. Retrieved April 12, 2013, from http://link.springer.com/article/10.1007/s11199-012-0228- 1\#page-1 The Wage Gap by Gender \& Race Timeline History (White, Black, Hispanic, Men\& Women). (n.d.). Infoplease: Encyclopedia at Infoplease.com. Retrieved April , 2013, from http://www.infoplease.com/ipa/A0882775

[29] Susan, Trentham., Laurie, Larwood.(2008). Gender discrimination and the workplace: an examination of rational bias theory, Sex Roles. A Journal of Research, 38, 1-28.

[30] Tickner, Ann J. (2001). "Patriarchy". Routledge Encyclopedia of International Political Economy: Entries PZ. Taylor \& Francis. pp. 1197-1198.

[31] Uzma Shoukat.(2004). Literacy and women's identity, Proceedings of the International Conference on Social Sciences: Endangered and Engendered, Fatima Jinnah Women University, Rawalpindi, Pakistan, 84-96.

[32] Wayne, F. Casico. (2005). Managing Human Resource, Productivity, Quality of work life, Profits, McGraw Hill Internationals (4 th edition).

[33] Ziaullah. (2008). Workforce management challenges for contemporary HR Managers: Review of Workforce Diversity and Employee Empowerment, Pak Management Review, XLV(1), 25-33. 